\title{
The Passage of Time in Tom Stoppard's Arcadia
}

\author{
Junyi Zhou \\ Chongqing Illume Research Education Technology Co., Ltd., Chongqing, China \\ cassidyc0802@outlook.com
}

Keywords: time; quantum physics; literature; history; knowledge; love

\begin{abstract}
Tom Stoppard's play Arcadia contributes to how Stoppard brings together the themes of the play, and provides its central plot-line. First of all, Stoppard employs juxtaposition to convey one of the major themes in the play: the conflict of emotion and intellect. Moreover, Stoppard's use of two timelines enables Stoppard to explore the historical progression of knowledge, therefore addressing the theme of wisdom and knowledge. Lastly, time manifests itself in the discussion of sex in the play; it has the same effect as sex - it links characters from two generations together due to their shared desire for discovery.
\end{abstract}

As a play that masterfully explores the nature of truth and time, the differences between the Classical and Romantic temperament, (According to Stoppard: "those who have particular respect for logic, geometry and pattern and those with a much more spontaneous, unstructured communion with nature ${ }^{1}$ ) and the disruptive influence of sex on our orbits or life - "the attraction which Newton left out”, Tom Stoppard's Arcadia needs a means to bring all the subjects together, through two different plot lines (that is, the plot line of the past and the plot line of the present) - and time acts as a particularly effective tool to accomplish the goal. As Paul Edwards stated in his article "Science in Hapgood and Arcadia", "The brilliantly conceived structure of Arcadia enables the audience to witness the effects of time in Sidley Park, since the play is set in two different periods, but in the same garden room of the stately home." ${ }^{2}$ Enoch Brater raised the similar claim of time in the world of Arcadia: "An apple and a tortoise and 'and old-fashioned theodolite' exercise a similar mantic power in Tom Stoppard's Arcadia."3 This essay will survey how the presentation of time in Arcadia contributes to how Stoppard brings together the themes of the play, and provides its central plot-line.

Stoppard employs juxtaposition to convey one of his major themes: the conflict between emotion and intellect. He does so by using two different characters to represent this clash from the two different time periods presented in the play. Time itself acts as a tool for Stoppard to compare how this conflict plays out in different historical moments and to build up the characters. In the world of Arcadia, intellectual pursuits and emotional fulfillment are often in conflict. This discord is especially conspicuous in the protagonist Thomasina's story. When she asks Septimus, her tutor, what the term "carnal embrace” means, Septimus' initial response is to attempt to avoid the question, and provide a fumbling response: "Carnal embrace is the practice of throwing one's arms around a side of beef." The inquiry of sexual knowledge gets in the way of their lessons, making emotion and intellect conflict. This develops across the play, as Thomasina begins to develop feelings for Septimus' friend, Lord Byron, and later, for Septimus himself. Time then takes us back to the present to meet the author Hannah Jarvis. Unlike Thomasina, Hannah is not swayed by romantic pursuits; she believes that following any instincts that could lead to a romantic relationship would hinder her from doing her work well. She embraces rationality and detests the opposite; she refuses to be kissed; she rejects Bernard and dives deeply into her own work. Paul

\footnotetext{
${ }^{1}$ David Nathan, 'In a Country Garden, (if it is a Garden),” reprinted in Delaney, ed., Stoppard in Conversation, p.12

2 Paul Edwards, 'Science in Hapgood and Arcadia', Cambridge Companion to Tom Stoppard, (Cambridge University Press, 2006) p.176

3 Enoch Brater, 'Playing for Time (and Playing with Time) in Tom Stoppard's Arcadia', Comparative Drama, Volume 39, Number 2, Summer 2005, p. 160
} 
Edwards again made remarks on such juxtaposition: "The play turns around the intuitive - romantic versus rational - classical dichotomy sketched by Hannah, even in its treatment of science and the recoverable of irrecoverable past." 4 In the struggle between emotion and reason in Arcadia, Hannah is the epitome of reason. The way that time moves smoothly across different time periods, allows to compare these juxtaposed characters which brings out one of the central themes in the play.

The second theme that time addresses is the topic of wisdom and knowledge. The use of two timelines in Arcadia provides Stoppard a way to explore the historical progression of knowledge. Thomasina brings up an idea she thinks of in the world of the play, that

"Each week I plot your equations dot for dot, $x$ s against $y$ s in all manner of algebraical relation, and every week they draw themselves as commonplace geometry, as if the world of forms were nothing but arcs and angles. God's truth, Septimus, if there is an equation for a curve like a bell, there must be an equation for one like a bluebell, and if a bluebell, why not a rose?” (1.3)

In response, Septimus says that "[God] has mastery of equations which lead into infinities where we cannot follow.” (1.3.) Thomasina, however disagrees, as she firmly believes that she must work out a way to solve all problems. Where Septimus would leave some questions for God to answer, Thomasina wants to plot a leaf and deduce its equation. Unfortunately, Thomasina dies a tragic death at the age of sixteen and her later love Septimus becomes a hermit, solving her equations for all his life but could never get the answers due to technological issues. Stoppard then takes us back to the present time, in which the mathematician Valentine successfully extrapolates Thomasina's ideas using a computer, relating her equations to the concept of entropy. This plotting directly draws on Septimus telling Thomasina that she should not be upset at the loss of the library of Alexandria because "we shed as we pick up, like travellers who must carry everything in their arms, and what we let fall will be picked up by those behind... The missing plays of Sophocles will turn up piece by piece, or be written again in another language.” (1.3) This suggests that Septimus maintains a "classical, Newtonian faith that they (meaning the reduction of anything to ashes) do reverse themselves, or that the principle of the conservation of energy means that the prior conditions will return again." 5 The passage of time allows Thomasina's discoveries to be found, contemplated, and decoded in the world of the play; it also give us a hint that although time itself is irreversible, knowledge can still float through it as a constant, waiting to be found by another group of people or perhaps another generation.

Time also manifests itself in the discussion of sex in the play. According to Valentine, sex is "the attraction that Newton left out" (2.7), an irrational force that brings people together yet splits them apart according to its own non-scientific rules, with unpredictable and dangerous results. Time has the same effect as sex - it links characters from the two generations together due to their shared desire for discovery. Through these connections the characters establish a solid bond in which the younger generation pick up the traces that the older generation leave behind and eventually understand the science behind their discoveries. For example, Valentine relates Thomasina's ideas to the concept of entropy - the idea that everything in the universe becomes more and more randomly distributed until it is a total disorder, and it is the same for the concept of time. Time breaks up everything and brings it back together; no matter how hard one might try to preserve reason and order, under the influence of the passage of time everything is doomed to be destroyed. Therefore, at the end of the play, Septimus finally resolves and gives up to time and reason, indulging himself in romantic love by waltzing with Thomasina. Again, time brings us back to the present in which Hannah Jarvis also gives in and dances with Gus, for Septimus and Hannah both understand the destructive influence of time and choose to live in the present and to accept the outcome of human desire. As Hersh Zeifman successfully put it: “...in the midst of a chaotic,

\footnotetext{
4 Paul Edwards, 'Science in Hapgood and Arcadia', Cambridge Companion to Tom Stoppard, (Cambridge University Press, 2006) p.178

5 Paul Edwards, 'Science in Hapgood and Arcadia', Cambridge Companion to Tom Stoppard, (Cambridge University Press, 2006) p. 179
} 
disordered world, even in the face of death - especially in the face of death - we must still leave ourselves open to romance, to the vagaries of erotic desire." 6

Taking all things into consideration, time acts as both a strong force in the world of Arcadia and a link to bring all the themes together. It maintains its irreversibility and flows through the conflict between emotion and intellect, the pursuit of knowledge, and Eros - in another word, sex and desire. It also serves as an effective tool to spread out two different timelines, and to weave the themes into the timelines.

\section{References}

[1] Enoch Brater, 'Playing for Time (and Playing with Time) in Tom Stoppard's Arcadia', Comparative Drama, Volume 39, Number 2, Summer 2005, p. 160

[2] Paul Edwards, 'Science in Hapgood and Arcadia', Cambridge Companion to Tom Stoppard, (Cambridge University Press, 2006) pp. 176-179

[3] David Nathan, 'In a Country Garden, (if it is a Garden)," reprinted in Delaney, ed., Stoppard in Conversation, p.12

[4] Hersh Zeifman, 'The comedy of Eros: Stoppard in love', Cambridge Companion to Tom Stoppard, (Cambridge University Press, 2006) p. 190

\footnotetext{
${ }^{6}$ Hersh Zeifman, 'The comedy of Eros: Stoppard in love', Cambridge Companion to Tom Stoppard, (Cambridge University Press, 2006) p. 190
} 